УДК 37.016:811.111(07)

DOI: $\underline{10.35619 / \text { iiu.v2i11.217 }}$

\begin{abstract}
Alla Fridrikh
$\mathrm{PhD}$ in Pedagogy, Associate Professor, Associate Professor at Practice of English Language Department, Rivne State University for the Humanities, Rivne, Ukraine ORCID: 0000-0001-9072-1845 e-mail: allafridrikh@gmail.com

Svitozara Bihunova

$\mathrm{PhD}$ in Psychology, Associate Professor, Associate Professor at Practice of English Language Department, Rivne State University for the Humanities,

Rivne, Ukraine

ORCID: 0000-0001-6860-6939 e-mail: svitozara.rv@gmail.com

Halyna Nikolaichuk PhD in Pedagogy, Professor, Dean at the Faculty of Foreign Philology, Rivne State University for the Humanities,

Rivne, Ukraine

ORCID: 0000-0001-5637-4288

e-mail: nikolaychukgalyna@gmail.com
\end{abstract}

\title{
INQUIRY AS A KEY TO DEEPER LEARNING
}

\begin{abstract}
In spite of the fact that critical thinking is a vital skill not only during studying at university but in everyday life either, students are often unprepared for critically thinking when they start their studies. That is why it is so necessary to explain how to use practical strategies for developing these skills for a successful academic life. First of all, teachers should always bear in mind Bloom's Taxonomy as it helps them to find the correct way for teaching showing the nearest and the furthest goals in their work. The levels start from the simplest and go to the most complicated ones showing that no one can acquire a higher level without mastering the lower ones and that their acquiring is necessary for bringing up critically thinking students.

Creating a culture of inquiry is constant work which grows problem-solving learners with deeper understanding of important knowledge. Being convinced that a significant tool for creating a culture of inquiry is essential questions that drive and motivate learning, the authors have designed some recommendations that can encourage inquiry-based learning process and involve students in it. As inquiry-based learning elevates students' autonomy and collaboration, and helps to create a culture focused on researching rather than reproducing information, the authors consider that teachers should focus on question formulation technique. Besides, four phases of inquirybased learning have been distinguished and described in details.
\end{abstract}

Key words: inquiry, inquiry-based learning, critical thinking, Bloom's Taxonomy, questions.

(C) Fridrikh A., Bihunova S.,

Nikolaichuk H., 2020 
Problem statement. Critical thinking is a vital skill at university and later in life. University study introduces us to new concepts, ways of learning and requires thinking critically. We need to know how to question information sources and how to evaluate different arguments. Despite critical thinking being so important, students are often unprepared when they start their studies. So there is the need to explain how to use practical strategies to develop these skills for a successful academic life.

The research aim and objective is to find out the ways of creating the culture of inquiry in the classroom. The main tasks are to distinguish the characteristics and the peculiarities of the inquiry-based learning, the phases of its implementation into educational process, and the strategies for effective creating an inquiry-driven classroom.

Presenting the main research material. As we want our students to be initiative, smart, creative, inventive and thoughtful, understanding Bloom's Taxonomy is urgent and obligatory for teachers as far as it helps them to find the correct way for teaching showing the nearest and the furthest goal in their work. That is why we think it is necessary to explain it briefly. It should be mentioned that Bloom's Taxonomy (Bloom, 1956) just shows the order for people's cognitive behavior and due to this it can easily be used in any sphere of teaching.

Bloom's Taxonomy consists of six levels which are divided into two groups: the Lower Order Thinking Skills (LOTS) and the Higher Order Thinking Skills (HOTS). It is easy to notice that levels start from the simplest and go to the most complicated showing that no one can acquire the higher ones without mastering the lower levels (Anderson, 2013).

The basic level is remembering and possible activities are: reciting poems, listing the main events of the story, naming the characters, etc. In other words, the main point here is that students try to recollect and remember the previously given information. As we are speaking about inquirybased learning, it goes without saying that we should teach students to ask questions. So, the first step for them on this level is asking questions for remembering facts, such as Who is the author of the story? When / Where did the event take place? Can you name the main characters? What did they do after....? What happened after...? Who helped the main character? Etc.

The second level is understanding. Possible exercises here are: writing the summary, retelling the story, explaining the difference between the events / characters, i.e. students are trying to understand and interpret the given material. In such a way, their next step in being taught to ask questions is attempts to explain the ideas. The examples of probable questions are Can you retell the story / the episode / the film in your own words? What is the main idea of the book / the film / the episode? Can you predict the end of the story / the film? Who do you think is the real hero? How would you explain the reason for her / his / their behavior? Etc.

The third level of Bloom's Taxonomy is Applying and possible tasks are: making up a puzzle game using the learnt material, illustrating a story, making a collage about an event, etc. which demonstrate students' ability to use the given information in a new way while solving the problem. The question patterns here are What would happen with the main character if ....? What can you use to explain the problem? How would you / your group solve the task? What would you change if you were a director / a minister /...? Etc.

These three above mentioned levels are LOTS and their acquiring is necessary for developing the Higher Order Thinking Skills which help bring up critically thinking students.

The fourth level (and the first of HOTS) is analyses. Example exercises here are: making up a questionnaire to collect some information, constructing a graph to depict the gathered information, preparing a report, putting up a play, etc. In such a way students try to break the information down for its better understanding. Possible questions are What was the climax in the story? Is the 
information based on opinions or on facts? Who do you think was the real victim (or the villain) in the film / in the story? Can you explain the reasons of the characters' behavior? Etc.

The next level is evaluating. The following activities can be used as possible tasks: finding possible solutions to a given problem, discussing the pros and cons of the problem, writing an appeal to public opinion for changes in people's attitude to..., etc. Tasks of this level help students use the information for expressing and justifying their own points of view. That is why such types of questions can be used as What do you think about...? What are your arguments for / against....? What consequences would happen if....? What improvements to ...would you propose? Do you agree or disagree with the .... and why? Etc.

And the final level of HOTS is creating. As students show their understanding and ability to use the previously learnt, examined, justified and assessed material and on the basis of this they create new ideas, the following exercises can be given as examples: making poems or chants, writing an essay, making a presentation, doing a project, etc. As question patterns we propose What could have happened if....? What solution / solutions might be proposed to...? What is the best way out of the situation? How could you change for the better....? Etc.

As you can see, a culture of inquiry grows problem-solving learners with deeper understanding of important knowledge and begins with a welcoming climate of trust where students understand the value of questions and the adventure of seeking answers. However, creating a culture of inquiry takes constant work. Teachers need to establish it from the first day in the classroom, and work to keep it vital throughout the year. If students don't feel welcome in the classroom, they won't ask questions or engage in the learning. Teachers need to make sure that students feel valued in their classroom and for this reason teachers should create activities for students to share their passions and interests. There are a lot of strategies to make students feel welcome, but don't forget that this must be ongoing and year round to ensure that it truly becomes a reflection of the classroom climate.

What is more, many students need support in asking questions and creating different kinds of questions for different situations. Teachers should use a variety of strategies, in particular (1) structured protocols, (2) question starters and stems, (3) to create an ongoing list of questions that could be investigated, to support students in asking meaningful questions. Teachers should find ways to value all questions that come into the classroom and thank students for them, because these inquiries come from their minds.

A significant tool for creating a culture of inquiry is essential questions that drive and motivate learning. Wiggins and Mc Tighe articulate this effect in their book "Essential Questions: Opening Doors to Student Understanding (McTighe \& Wiggins). As some questions might "close doors" for students, the questions that will "open doors" inviting them into learning should be created. These questions are provocative, open-ended, and aligned to the content, but they also allow space for exploration; there should be no single right answer. It is better when the answer requires students to justify their way of thinking, to support their ideas, to give strong evidence and proof. Students may not find the right answer immediately, as they can change their ideas or find another perspective. They should focus on the process of inquiry, but not the answer. Such questions can be teacher-created, as well as co-constructed or student-designed.

Effective assessments are also significant points in creating of the culture of inquiry in the classroom:

- Do we focus on complexity of the answer and justification of the findings?

- Do we honor student voice and choice?

- Do we give feedback that allows students to investigate their own questions aligned to the content? 
Following these points, we can create a culture where students are constantly working on, valuing inquiry as it should be a vital part of the instruction for students.

Now researchers are pretty sure that " $21^{\text {st }}$ century skills" such as curiosity, persistence, collaboration, growth mindset, critical thinking, and creativity are improving learning across all academic domains (Kuhlthau, 2007).

Curiosity is considered to be a powerful catalyst for learning. Students, discovering the world around them, reveal their interests by asking a lot of various questions. Thus, the goal of education should be to grow students that are ready to solve problems and think critically. That is why asking questions is a necessary skill in the educational process (Nayfeld). For this reason, we prioritize question asking as an essential part of inquiry-based learning. Besides, we highly recommend educators to create environment that encourage curiosity and inquiry. We have designed some recommendations that can encourage inquiry-based learning process and involve students in it.

\section{Turn a lesson into a project (or project-based learning opportunity).}

A teacher can put a meaningful question for students to investigate, show them how to find answers using media, technology or other resources, and, most importantly, show them that their questions can lead to experiments and explorations, gaining new knowledge and solving problems.

\section{Stop criticizing and being the expert.}

When a question is asked, there are ways a teacher can interact:

- $\quad$ Answer the question as best as you can and keep going with your topic.

- Say "That's a great question... how can we find out the answer?"

Students may not know the answer. That will lead to more in-depth and more interesting discussions. Tell the students that there are different perspectives and ask for suggestions of the problem. This learning will be more meaningful and productive when it will be student-oriented and autonomous, and when the whole group is actively involved in finding solutions.

\section{Have a plan for questions.}

A teacher should create a classroom environment where meaningful questions are welcomed. However, if we allow every question to lead to new discussion or investigation in that moment, we will never solve the given problem. This is why it's important to have a question action plan. We can drive inquiry in the classroom by using planned questions.

\section{Highlight the evolution of student questions.}

We consider highlighting of not just questions but the evolution of questions to be the vital evidence that culture of inquiry is improving in our classroom.

As the nature of education is constantly changing, students need to gain the experience through problem-solving and reflection, paying attention to the core elements of the inquiry process. Here are some suggestions to inquiry-based learning (McTighe \& Wiggins).

Research Steps: discover problems and define questions, gather data, analyze and interpret, conclude and report.

To reach learning through inquiry students should ask themselves whether information is incomplete or outdated. Does the problem represent local or global perspectives? What are their assumptions or biases? Do the data and source provide adequate, valid and reasonable information or evidence for their conclusions? Where can you search what you need to develop comprehensive understanding? Do you need more materials on the topic? How can we learn to use content, discourse, or other data analysis methods during practicing the course? What new problems have you discovered? How can you present it?

In order to develop a researcher's mindset we suggest questioning the foundations of the materials we find, and looking for gaps in the literature. When we have biases, we recommend using them as the basis for reflection. Focus on different perspectives, including the use of open 
access or other databases. Brainstorm ways to reach the inquiry-based learning by using various methods, and then reflect on students' interpretation of findings.

When we are working with students by moving from transmission to exploration, we might help them to realize the importance of inquiry. Being prepared to ask problematic questions and think critically, they will be beneficial not only in the classroom, but also in their everyday lives. They will develop mindsets and skill sets that will prepare them to be researchers in the modern world.

We should use such questions to drive inquiry in project-based learning, that can be a powerful teaching and learning strategy. The key task is to increase the quality of student inquiry. Inquirybased learning elevates students' autonomy and collaboration, and helps create a culture focused on researching rather than reproducing information. We think that teachers should focus on question formulation technique, that is step-by-step process: question focus, producing question, improving question, prioritizing questions, putting into action, answering, reflection (Perkins; Nayfeld).

Question Focus is the first step, which actually provokes a student to think. Students then produce "question-storming" that works best when they are in small groups. This collaboration is powerful as students are brainstorming to answer these questions without judging. It should be noted that the shift from being asked for answers to being asked for questions can be powerful in building inquiry learning environment. As students work through the remaining steps, the opportunities for meta-cognition are improving.

In spite of the fact that there are several different inquiry-based learning models, but they have common key elements:

- learning focuses around a meaningful problem that demands consideration of diverse perspectives and findings;

- academic content-learning occurs as an essential part of the educational process as students work towards finding solutions;

- $\quad$ students collaborate instantly and participate in the learning process actively and autonomously/ it is a student-centered approach;

- teachers provide students with learning supports and multiple reliable sources of information to assist learners in finding solutions;

- $\quad$ students share/ defend their solutions or product in public;

- the learning process has phases which are regulated by the frame instruction.

We distinguish four phases of inquiry-based learning: interaction (the task of this phase is to involve students into the process. During this phase it is significant to focus on the necessity for inquiry), clarification (the task of this phase is to summarize and categorize learning with the support of a teacher or an expert), questioning (the main idea is to ask questions in order to conduct continued, self-directed inquiry), designing (to create relevant and curiosity-driven product with the aim to justify the inquiry) (Heick).

Let us describe these phases more detailed. As for interaction it can be of such types:

- $\quad$ student-to-materials / resources. It can be done through formal or informal means. Thus, researching as well as reading digital or social media can be used (digital, text, pure data, etc.);

- student-to-peers. This interaction is student-oriented, even autonomous to some extend. Students search for information and find new perspectives, discuss and analyze it in groups. We recommend using the jigsaw method and regrouping here; 
- student-to-experts. This interaction is also student-oriented as students can consult not only the teacher but any person they think is worth to and at any time it is necessary for them. Also students can choose whether they need this cooperation or they can skip it.

The teacher's role during this first phase is to facilitate the learning process, focusing on valid and reliable resources, inspiring curiosity, and cognitive coaching. Teachers should ask provoking questions but - what is very important - without their evaluation. They can provide different examples and motivate students' thinking.

And the students' task is to seek for ideas, study resources, and collaborate. They have to skim a lot of media and different resources. They have to ask themselves: What do I want to know about this topic? What kinds of resources might help? What sources of information are available, reliable and valid to me? What do my peers know? What's worth studying? What perspectives and data are available to me? Will this benefit my research?

During the second phase, that is clarifying, students skim and read a variety of resources. On this stage of the inquiry the learning process is centred on students. They clarify not only their own thinking, but the ideas for projects, scientific challenges, need for designing a product or action as well. They analyze data, identify and clarify misconceptions. Students should look for answers and solutions of the problem; distinguish between proved facts and opinions; evaluate the relevance and validity of sources.

Teachers during this phase should offer non-evaluative and frequent feedback; provide the frame to students' solutions, focusing on the way of their thinking by asking appropriate questions: What's accessible, and what's not? What are the perspectives or opportunities for collaboration? Will this data clarify my further thinking? How do I get or know this? How do I know the info is valid? Does my research raise new questions?

The key idea of the third phase, that is questioning, is to provoke self-directing inquiry by asking questions. This phase is a critical one of inquiry-based learning process. Students often move back and forth between phases, and new skills and understandings can be obtained during this phase. Inquiry-based learning is more about the process of learning than other traditional academic forms, which can require both students and teachers to adjust their measures of progress and success. Students monitor themselves, their findings and outcomes by asking themselves.

Teachers create sets of questions, design concept-mapping tools to analyze students' thinking; facilitate project-based learning classes and Socratic seminars. They can provoke students by asking such king of questions: Where are my knowledge gaps? What is beyond my reach? How can I solve this problem in further learning / living?

The fourth phase is designing an accessible and relevant product that justifies the inquiry. This is the final stage of the inquiry-based learning process. On this phase students are focused on designing solutions to the problems. They have to show logical understanding of their own learning pathway. During this stage they are self-directed, collaborate with peers. Teachers reflect back on entire process (i.e., how have we got to this point? What is the evidence of the right solution? Are there other perspectives?)

Afterwards it can be helpful for students to reflect in the inquiry-based learning process through questions such as: What skills did I depend on? If I had more time or resources, what else could I have done? What do I understand more deeply, and how do I get this? What is the role of inquiry in learning? Will I reach these results without autonomous inquiry-based learning process? Where else can I apply these skills?

Conclusions and further research prospects. The created model is recommended to be used as a guide for teachers, as it recommends problem-solving and self-monitoring questions for 
students at each stage. Inquiry-based learning is an approach that can easily combine project-based learning, challenge-based learning, problem-solving, and other trends in education.

\title{
REFERENCES
}

Bloom, B. (ed.) (1956). Taxonomy of Educational Objectives: The Classification of Educational Goals, Handbook 1: Cognitive Domain. New York: Longmans, Green and Company. 214 p.

Anderson, L. (2013). A Taxonomy for Learning, Teaching, and Assessing: A Revision of Bloom's Taxonomy of Educational Objectives, Abridged Edition. Pearson New International Edition. 336 p.

McTighe Jay, Wiggins Grant. Essential Questions: Opening Doors to Student Understanding. URL: $\quad$ http://www.ascd.org/publications/books/109004/chapters/What-Makes-a-QuestionEssential\%A2.aspx [Accessed 20/03/20]

Kuhlthau, C., Maniotes, L., \& Caspari, A. (2007). Guided Inquiry: Learning in the 21st Century. London: Libraries Unlimited. $170 \mathrm{p}$.

Nayfeld Irena. 6 Strategies for Creating An Inquiry-Driven Classroom. URL: https:/www.teachthought.com/learning/6-strategies-for-creating-an-inquiry-driven-classroom/

Perkins Drew. Using The QFT To Drive Inquiry In Project-Based Learning. URL: https://www.teachthought.com/project-based-learning/using-the-qft-to-drive-inquiry-in-projectbased-learning/ [Accessed 20/03/20]

Heick Terry. 4 Phases Of Inquiry-Based Learning: A Guide For Teachers. URL: https:/www.teachthought.com/pedagogy/4-phases-inquiry-based-learning-guide-teachers/ [Accessed 20/03/20]

\section{ПОШУК ЯК КЛЮЧ ДО ПОГЛИБЛЕННЯ НАВЧАННЯ}

\author{
Фрідріх Алла \\ кандидат педагогічних наук, доцент, \\ доцент кафедри практики англійської мови \\ Рівненського державного гуманітарного університету, \\ м. Рівне, Україна \\ ORCID: 0000-0001-9072-1845 \\ e-mail: allafridrikh@gmail.com \\ Бігунова Світозара \\ кандидат психологічних наук, доцент, \\ доцент кафедри практики англійської мови, \\ Рівненського державного гуманітарного університету, \\ м. Рівне, Україна \\ ORCID: 0000-0001-6860-6939 \\ e-mail: svitozara.rv@gmail.com
}


Ніколайчук Галина

кандидат педагогічних наук, професор, декан факультету іноземної філології Рівненського державного гуманітарного університету, м. Рівне, Україна ORCID: 0000-0001-5637-4288 e-mail: nikolaychukgalyna@gmail.com

Анотація. Незважаючи на те, що критичне мислення $є$ життєво важливим навиком не лише під час навчання в університеті, а й у повсякденному житті, студенти часто не готові до нього. Ось чому вже на початкову етапі навчання в закладі вищої освіти слід пояснити, як використовувати практичні стратегії розвитку цих навичок для успішного академічного життя. У своїй діяльності вчителям слід опиратися на таксономією Блума, оскільки це допомагає їм зорієнтуватися на правильному способі навчання, враховуючи найближчі цілі та подальші перспективи. Ніхто не може оволодіти вищим рівнем не оволодівши нижчим, а це потрібно для виховання критично мислячих студентів.

Навчання через пошук - це наполеглива робота, яка сприяє формуванню в студентів глибокого розуміння важливості знань. Авторами статті розроблені методичні рекомендації, які сприятимуть організації пошуково-дослідного навчання студентів. Вони включають: розробку уроків-проєктів; висловлювання експертної оцінки замість критики; планування запитань та їх еволюція.

Оскільки пошуково-дослідне навчання підвищує самостійність і співпрацю учнів та допомагає створити середовище, зосереджене скоріше на дослідженні, а не на відтворенні інформації, автори вважають, що важливою $є$ техніка формулювання питань. Крім того, було виділено чотири фази пошуково-дослідного навчання, а саме: взаємодія (завдання цього етапу - залучення студентів до процесу навчання та зосередження їх уваги на необхідності пошуку), уточнення (завдання цього етапу - узагальнення та категоризація навчання за підтримки вчителя або експерта), опитування (головна ідея - ставити запитання для того, щоб продовжувати самостійний пошук), проєктування (створення релевантного та цікавого результату з метою підтвердження пошуку). Всі ці фази детально описані в статті.

Ключові слова: пошук, пошуково-дослідне навчання, критичне мислення, таксономія Блума, запитання.

Стаття надійшла до редакиії 03.02.2020 p. 